\title{
Enhanced Polymerase Chain Reaction Methods for Detecting and Quantifying Phytophthora infestans in Plants
}

\author{
Howard S. Judelson and Paul W. Tooley
}

First author: Department of Plant Pathology, University of California, Riverside 92521; and second author: U.S. Department of Agriculture, Agricultural Research Service, Foreign Disease-Weed Science Research Unit, 1301 Ditto Ave., Ft. Detrick, MD 21702. Accepted for publication 26 June 2000.

\begin{abstract}
Judelson, H. S., and Tooley, P. W. 2000. Enhanced polymerase chain reaction methods for detecting and quantifying Phytophthora infestans in plants. Phytopathology 90:1112-1119.

Sensitive and specific primer sets for polymerase chain reaction (PCR) for Phytophthora infestans, the oomycete that causes late blight of potato and tomato, were developed based on families of highly repeated DNA. The performance of these primers was compared to those developed previously for the internal transcribed spacer (ITS) of ribosomal DNA. The detection limit using the new primers is $10 \mathrm{fg}$ of $P$. infestans DNA,

or 0.02 nuclei. This is about 100 times more sensitive than ITS-directed primers. Nested polymerase chain reaction (PCR) allows the measurement of down to $0.1 \mathrm{fg}$ of DNA using the new primers. To enhance the reliability of diagnostic assays, an internal positive control was developed using an amplification mimic. The mimic also served as a competitor for quantitative PCR, which was used to assess the growth of $P$. infestans in resistant and susceptible tomato. A key dimension of this study was that two laboratories independently checked the specificity and sensitivity of each primer set; differences were noted that should be considered when PCR is adopted for diagnostic applications in any system.
\end{abstract}

Late blight of potato and tomato has become increasingly severe due to the appearance of fungicide-resistant and aggressive genotypes of the pathogen, Phytophthora infestans (Mont.) de Bary (11). Many strategies for controlling late blight involve detecting or quantifying $P$. infestans within plant tissue. Checking seed potatoes and tomato transplants for infection is a priority since these are sources of inoculum $(1,11)$. Many seed certification agencies in the United States accordingly established maximum infection tolerances of 0 to $1 \%$ for tubers. Postharvest detection of late blight is also important, as a few infected tubers can compromise an entire storage facility (26). Studies of the disease cycle and resistance breeding programs also benefit from accurate measurements of pathogen growth (7).

Traditional methods for detecting $P$. infestans involve visual examination or culturing from plant tissue. However, visual inspection misses outwardly asymptomatic infections and is confounded by the similarity of symptoms caused by $P$. infestans and other pathogens. Isolating $P$. infestans is difficult when secondary microflora or other species of Phytophthora are present, and involves a timeframe incompatible with realities of the marketplace. Immunodetection is potentially rapid but existing antibodies for $P$. infestans lack specificity (12). Strains of $P$. infestans with marker transgenes may aid experimental studies of pathogen growth (16) and host resistance (17), but regulations for transgenics limit such applications.

Polymerase chain reaction (PCR) is now established as an important technique for detecting pathogens, offering higher sensitivity and specificity than many traditional methods (13). PCR protocols for detecting various Phytophthora spp. targeted intergenic spacer regions (ITS) of ribosomal DNA $(3,19,24,25,29,32)$ and other low-to-middle copy sequences $(4,8,18,22)$. Such assays

Corresponding author: H. Judelson; E-mail address: howard.judelson@ucr.edu

Publication no. P-2000-0803-01R

This article is in the public domain and not copyrightable. It may be freely reprinted with customary crediting of the source. The American Phytopathological Society, 2000. reported detection thresholds near the picogram range and varying levels of species specificity.

The impetus for the present study was the identification of DNA sequences from $P$. infestans that existed at exceptionally high copy numbers and were species-specific based on hybridiza-

TABLE 1. Isolates of Phytophthora tested in polymerase chain reaction assays

\begin{tabular}{|c|c|c|c|}
\hline Name $^{a}$ & Mating type & Origin & Place and year isolated \\
\hline 115.11 & A2 & Solanum tuberosum & Canada; 1994 \\
\hline 127 (US-1) & A1 & Solanum tuberosum & United States; 1982 \\
\hline 198 (US-1) & A1 & Solanum tuberosum & United States; 1994 \\
\hline 199 (US-8) & A2 & Solanum tuberosum & United States; 1994 \\
\hline 510 & A2 & Solanum tuberosum & Mexico; 1983 \\
\hline 511 & A1 & Solanum tuberosum & Mexico; 1983 \\
\hline 529 & A1 & Solanum tuberosum & Mexico; 1983 \\
\hline 541 & A1 & Solanum tuberosum & Mexico; 1983 \\
\hline 550 & $\mathrm{~A} 2$ & Solanum stoloninferum & Mexico; 1983 \\
\hline 580 & A1 & Solanum tuberosum & Mexico; 1983 \\
\hline 582 & A1 & Solanum tuberosum & Mexico; 1983 \\
\hline 618 & $\mathrm{~A} 2$ & Solanum tuberosum & Mexico; 1987 \\
\hline 654 & $\mathrm{~A} 2$ & Solanum tuberosum & Mexico; 1987 \\
\hline 1114 & A1 & Solanum tuberosum & Netherlands; 1985 \\
\hline 1163 & A1 & Solanum tuberosum & Poland; 1985 \\
\hline 1296 & A1 & Solanum tuberosum & United Kingdom; _b \\
\hline 1306 & A1 & Lycopersicon esculentum & United States; 1982 \\
\hline 1362 & A1 & Solanum tuberosum & Mexico; 1979 \\
\hline 1363 & A1 & Solanum tuberosum & Mexico; 1979 \\
\hline 1389 & A1 & Lycopersicon esculentum & United States; 1980 \\
\hline 1484 & A1 & Solanum tuberosum & United Kingdom; 1982 \\
\hline 6150 & A1 & Solanum tuberosum & Japan; 1988 \\
\hline 6162 & A1 & Solanum tuberosum & Japan; 1988 \\
\hline 6170 & A2 & Solanum tuberosum & Japan; 1988 \\
\hline 6736 & A1 & Solanum tuberosum & Rwanda; 1985 \\
\hline 7629 (US-6) & A1 & Solanum tuberosum & United States; - \\
\hline 7722 & A1 & Lycopersicon esculentum & United States; 1992 \\
\hline 7723 (US-7) & $\mathrm{A} 2$ & Lycopersicon esculentum & United States; 1992 \\
\hline 8811 & A1 & Solanum tuberosum & United Kingdom; 1988 \\
\hline 93H3 (US-7) & $\mathrm{A} 2$ & Lycopersicon esculentum & United States; 1993 \\
\hline E13a & $\mathrm{A} 2$ & Solanum tuberosum & Egypt; 1984 \\
\hline
\end{tabular}


tion assays (15). This paper describes the use of such sequences to develop primers for PCR that proved to be about 100 times more sensitive than those previously applied to P. infestans. Enhancements not generally described for other Phytophthora-directed PCR assays are also introduced, such as an internal control useful for diagnostic tests and a competitor-based method for in planta quantification. An additional dimension of this study was a comparison of the various primer sets in different laboratories.

\section{MATERIALS AND METHODS}

Sources of DNA. DNA was extracted from pure microbial cultures as described $(16,29)$. These cultures included isolates of $P$. infestans, other species of Phytophthora, and other genera as listed in Tables 1, 2, and 3, respectively. DNA from uninfected tomato or potato leaflets was obtained by CTAB extraction (21). DNA from tomato leaflets or potato tubers infected with zoospores of $P$. infestans $(16,29)$ was isolated by sodium hydroxide and Qiagen (Valencia, CA) ion-exchange methods, respectively (29). DNA concentrations were determined with spectrophotometric or dye-binding assays.

Oligonucleotides. PCR primers are listed in Table 4. PINF2, ITS3, PINF, and ITS5 were as described $(29,32)$. Primers based on DNA families AE7 and O8 (15) were designed using Oligo 4.03 (National Biosciences, Plymouth, MN). Primers were purchased by the Maryland (MD) Laboratory from Life Technologies (Gaithersburg, MD), and by the California (CA) Laboratory from Genosys (The Woodlands, TX) or Operon Technologies (Alameda, CA).

Amplifications. Reactions in CA and MD were performed in thermal cyclers from MJ Research (Model PTC-100; Waltham, MA) and Perkin-Elmer (Model 9600; Norwalk, CT), respectively, in $25 \mu \mathrm{l}$ using thin-walled vessels. In $\mathrm{CA}$, reactions were incubated $30 \mathrm{~s}$ at $94^{\circ} \mathrm{C}$, cycled 35 times between $94^{\circ} \mathrm{C}(30 \mathrm{~s})$, annealing temperatures of $50^{\circ} \mathrm{C}\left(30 \mathrm{~s}\right.$ for $\mathrm{O} 8$ and $\mathrm{AE} 7$ primers) or $55^{\circ} \mathrm{C}$ (30 s, for PINF2-ITS3 or PINF-ITS5 primer sets), and $72^{\circ} \mathrm{C}$ (60 s), and then held for $4 \mathrm{~min}$ at $72^{\circ} \mathrm{C}$ before cooling to room temperature. The same parameters were used in MD but each step lasted $15 \mathrm{~s}$, except for the terminal extension which was maintained at $4 \mathrm{~min}$. These times were selected based on the experience of each laboratory, since the rates of heating and cooling varies depending on the instrument and reaction vessels being used.

PCR of $\mathrm{O} 8$ and AE7 sequences was performed in $10 \mathrm{mM}$ Tris$\mathrm{Cl}(\mathrm{pH} 8.3), 50 \mathrm{mM} \mathrm{KCl}, 0.01 \%$ gelatin, $1.8 \mathrm{mM} \mathrm{MgCl} 2,0.1 \mathrm{mM}$ deoxynucleotide triphosphates (dNTPs), $0.4 \mu \mathrm{M}$ each primer, and 1 unit of TaqDNA polymerase. The latter was purchased by the

TABLE 2. Isolates of Phytophthora other than P. infestans, tested in polymerase chain reaction assays

\begin{tabular}{|c|c|c|c|}
\hline Species & Origin & Place and year isolated ${ }^{\mathrm{a}}$ & Name $^{b}$ \\
\hline P. boehmeriae & Capiscum annum (pepper) & Pakistan; 1989 & 7472 \\
\hline \multirow{2}{*}{ P. cactorum } & Malus pumila (apple) & Germany;1975 & 3406 \\
\hline & Malus pumila (apple) & United States (NY); - & 385 \\
\hline & Capsicum spp. (pepper) & United States (FL); 1983 & 302 \\
\hline P. cinnamomi & Anasus comosus (pineapple) & Taiwan; 1989 & 6379 \\
\hline P. citricola & Rubus idaeus (raspberry) & United States (CA); - & 1321 \\
\hline P. citrophthora & Theobroma cacao (cocoa) & Brazil; - & 1200 \\
\hline P. cryptogea & Prunus avium (cherry) & United States (CA); - & 389 \\
\hline \multirow[t]{2}{*}{ P. dreschleri } & Cajanus cajan (pigeon pea) & India; - & 1795 \\
\hline & Solanum tuberosum (potato) & Egypt; 1985 & 401 \\
\hline \multirow[t]{2}{*}{ P. erythroseptica } & Solanum tuberosum (potato) & Ireland; 1989 & 6180 \\
\hline & Solanum tuberosum (potato) & United States (ME); 1996 & 374 \\
\hline \multirow{2}{*}{ P. fragariae } & Fragaria spp. (strawberry) & United States (OR); 1989 & 3569 \\
\hline & Fragaria spp. (strawberry) & United States (MD); - & 394 \\
\hline & Ilex aquifolium (holly) & United States (OR); - & 343 \\
\hline P. inflata & Syringa vulgaris (lilac) & England; 1990 & 7492 \\
\hline P. insolita & Soil & Taiwan; 1979 & 6195 \\
\hline P. iranica & Solanum melongena (eggplant) & Iran; 1969 & 3882 \\
\hline P. katsurae & Cocos nucifera (coconut) & United States (HA); 1982 & 6921 \\
\hline P. lateralis & Chamaecyparis spp. (cedar) & United States (OR); 1988 & 3888 \\
\hline P. meadii & Hevea brasiliensis (rubber) & India; 1958 & 6503 \\
\hline P. megasperma & Asparagus officinalis (asparagus) & France; 1989 & 6616 \\
\hline & Pseudotsuga menziesii (Douglas fir) & United States (OR); - & 309 \\
\hline P. mirabilis & Mirabilis jalapa (four o'clock) & Mexico; 1985 & 3010 \\
\hline & Mirabilis jalapa (four o'clock) & Mexico; 1985 & 340 \\
\hline P. nicotiana & Nicotiana tabacum (tobacco) & United States (NC); - & 331 \\
\hline P. palmivora & Carica papaya (papaya) & United States (HA); - & 1787 \\
\hline
\end{tabular}

${ }^{a}$ United States locations include two-letter state designator or unknown (UN); - indicates unrecorded.

b Isolates with three-digit designations are from the authors' collections. Isolates with four-digit names are from the collection of M. Coffey, University of California, Riverside. 
CA and MD laboratories from Promega (Madison, WI) and PE Biosystems (Forster City, CA), respectively. Reaction conditions using PINF2 with ITS3, and PINF with ITS5, were as recommended by Tooley et al. (29) and Trout et al. (32). These differed from those listed above as PINF2 and ITS3 were used at $0.1 \mu \mathrm{M}$ with $0.2 \mathrm{mM}$ dNTPs, and PINF plus ITS5 were used with $0.08 \mathrm{mM}$ dNTPs and $1.9 \mathrm{mM} \mathrm{MgCl}_{2}$.

Amplification mimics were obtained by subjecting DNA from E. coli strain DH5 $\alpha$ to PCR with primers O8-3 and O8-4 using an annealing temperature of $35^{\circ} \mathrm{C}$. Reaction products were cloned into pGEMT Easy (Promega).

Gel electrophoresis and imaging. PCR products were resolved by electrophoresis in gels generally containing 1.4 to $2 \%$ agarose, or $0.75 \%$ Infinity Agarose Enhancer (Oncor, Gaithersburg, MD) $-0.5 \%$ agarose, in Tris-Borate-EDTA buffer $(90 \mathrm{mM}$ Tris-Borate and $2 \mathrm{mM}$ EDTA) and stained with ethidium bromide. Images were captured digitally or on film. Quantification was performed using images recorded by a Fluor-S CCD system with Quantity One software (Bio-Rad, Hercules, CA).

\section{RESULTS}

Selection of amplification targets. A study of repeated DNA in $P$. infestans suggested that families $\mathrm{O} 8$ and AE7 represented useful targets for sensitive and specific PCR (15). This was because these families contained 14,000 and 12,000 members per nucleus, respectively. Also, clones representative of each family did not cross-hybridize to DNA from other members of the genus besides $P$. mirabilis and $P$. phaseoli. These species, plus $P$. in- festans, are known to be closely related based on morphological (33) and DNA markers (29). The sequence of the O8 element displays weak similarity to reverse transcriptases (BLAST $E=6 \times$ $10^{-2}$ ), suggesting its evolution from a retroelement, and appeared to be dispersed throughout the genome (15). In contrast, AE7 showed no informative matches in database searches and exists in the genome as a moderately degenerate tandem repeat with a monomer size of $5.6 \mathrm{~kb}$.

Amplifications using two primer sets for $\mathrm{O} 8$ and one for AE7 (Table 4) revealed that the targets were well-conserved within $P$. infestans. The expected amplicons were obtained in each of 31 genetically and geographically diverse isolates tested (Fig. 1). Larger bands also frequently amplified, suggesting that some individual copies of the sequences existed in different conformations within each nucleus.

Sensitivity of PCR. Of the O8, AE7, and ITS-based primers $(30,32)$, the former were most sensitive at detecting DNA of $P$. infestans based on data from both the $\mathrm{CA}$ and MD laboratories (Fig. 2). Primers targeted against O8 were $\sim 100 \times$ more sensitive than ITS primers, displaying a detection limit near $10 \mathrm{fg}$ of genomic DNA. This is equivalent to 0.02 nuclei (31). In these amplifications and subsequent tests of specificity, the reaction conditions (including reagent composition and annealing temperatures) used for the ITS primers were as previously recommended $(30,32)$ and differed slightly from the conditions used for the $\mathrm{O} 8$ and AE7 primers as described previously.

A further increase in sensitivity was enabled by nested PCR against O8, which was possible since primer O8-3 bound within the 08-1/O8-4 amplicon. In four replicate nested assays, $1 \mathrm{fg}$ of

TABLE 3. Saprophytes and plant pathogens tested in polymerase chain reaction assays

\begin{tabular}{|c|c|c|}
\hline Species & Origin & Place and date isolated \\
\hline \multicolumn{3}{|l|}{ Oomycetes } \\
\hline Achlya bisexualis & Pond water & United States (NY); - ${ }^{\mathrm{a}}$ \\
\hline Halophytophthora spinosa 3823 & Rhizophora & Vietnam; 1972 \\
\hline Lagenidium giganteum & Mosquito & $-;-$ \\
\hline Pythium ultimum PY-4 & Potato & United States (ME); 1994 \\
\hline Pythium ultimum PY-5 & Potato & United States (ME); 1994 \\
\hline Saprolegnia monoica & Pond water & $-;-$ \\
\hline \multicolumn{3}{|l|}{ True fungi } \\
\hline Alternaria solani AS-1 & Potato & United States (FL); 1993 \\
\hline Fusarium oxysporum FS-1 & Potato & United States (FL); 1994 \\
\hline Fusarium sambucinum FS-3 & Potato & United States (ID); 1992 \\
\hline Helminthosporium solani HS-2 & Potato & Canada; 1995 \\
\hline Helminthosporium solani $\mathrm{HS}-4$ & Potato & Canada; 1995 \\
\hline Rhizoctonia solani $\mathrm{RZ}-1$ & Potato & United States (ME); 1995 \\
\hline Trichoderma harzianum K4 & Soil & United States (CA); - \\
\hline Verticillium albo-atrum VAA-1 & Potato & United States (MN); 1994 \\
\hline Verticillium dahliae VD-1 & Potato & United States (MN); 1995 \\
\hline \multicolumn{3}{|l|}{ Bacteria } \\
\hline Clavibacter michiganensis spp. sepedonicus & Potato & United States (ID); 1998 \\
\hline Erwinia carotovora ssp. Carotovora $\mathrm{ECC}-1$ & Potato & United States (CO); 1990 \\
\hline Erwinia chrysanthemi ECH-1 & Potato & United States (CO); 1990 \\
\hline Escherichia coli $\mathrm{DH} 5 \alpha$ & - & $-;-$ \\
\hline Pseudomonas solanacerum PSOL-1 & Potato & United States (FL); 1993 \\
\hline Pseudomonas syringae pv. tomato T23 & Tomato & United States (CA); 1985 \\
\hline
\end{tabular}

${ }^{a}$ Unrecorded, unknown, or not relevant.

TABLE 4. Primers used in this study

\begin{tabular}{|c|c|c|c|}
\hline Primer set & \multicolumn{2}{|c|}{ Primer sequences $\left(5^{\prime}\right.$ to $\left.3^{\prime}\right)$} & Major amplicon from Phytophthora infestans \\
\hline O8-1, 08-2 & AAGATGATGTTGGATGATTG & TGCCTGATTTCTACCTTCT & $245 \mathrm{bp}$ \\
\hline O8-3, 08-4 & GAAAGGCATAGAAGGTAGA & TAACCGACCAAGTAGTAAA & $258 \mathrm{bp}$ \\
\hline AE7-1, AE7-2 & GCCGCCGACATATTGAAT & CAAATCTGCGAACGAGACAT & $171 \mathrm{bp}$ \\
\hline PINF2, ITS3 ${ }^{\mathrm{a}}$ & CGATTCAAATGCCAAGCTAAAG & GCATCGATGAAGAACGCAGC & $456 \mathrm{bp}$ \\
\hline PINF, ITS5 ${ }^{\mathrm{b}}$ & CTCGCTACAATAGGAGGGTC & GGAAGTAAAAGTCGTAACAAGG & $600 \mathrm{bp}$ \\
\hline
\end{tabular}

a Tooley et al. (29).

b Trout et al. (32). 
DNA was always detected while $0.1 \mathrm{fg}$ was detected half of the time. Stochastic processes or sequence heterogeneity may limit amplification at $0.1 \mathrm{fg}$, since this represents $<3$ copies of 08 .

In these reactions and those described below, the CA and MD laboratories intentionally used different sources of primers, buffers, nucleotides, $T a q$ polymerase, thermal cyclers, and $P$. infestans DNA as a real-world test of the robustness of the assays. Some differences between locations were noted. For example, the 08 primers were slightly more sensitive in MD than CA. Sensitivities of the AE7 and ITS-based primers also varied between CA and $\mathrm{MD}$, although neither were more sensitive than the $\mathrm{O} 8$ primers based on six side-by-side comparisons.

Specificity of PCR. The O8 and AE7 primers displayed adequate specificity based on amplifications using $1 \mathrm{ng}$ of DNA from 33 species of Phytophthora (Table 2), including all infecting potato or tomato (9); other oomycetes, true fungi, and bacteria including common pathogens of potato and tomato (Table 3 ); and plants. Representative gels from CA are shown in Figure 3. Clear bands were generally detected only against $P$. infestans (lane 1), $P$. mirabilis (lane 26), and $P$. phaseoli (lane 27). Primers developed

O8-1/08-2

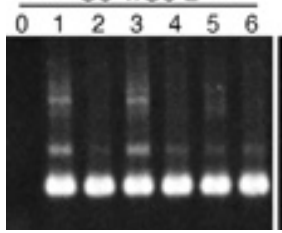

O $8-3 / 08-4$

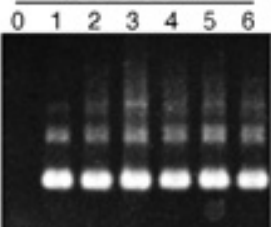

AE7-1/AE7-2

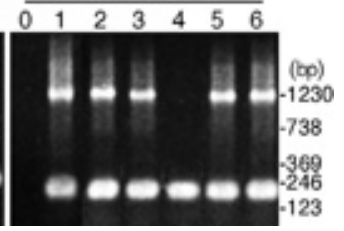

Fig. 1. Polymerase chain reaction using DNA from Phytophthora infestans. Reactions were executed using the indicated sets of primers with either no template (lane 0 ) or $1 \mathrm{ng}$ of DNA from isolates 1484, 582, 6736, 1362, 6170, and 1163 (lanes 1 through 6). Indicated in the right margin are size standards from a 123-bp ladder. Reactions were performed in the California laboratory as described in text. previously also failed to distinguish these species, which apparently evolved recently from a common ancestor (20,30). Such cross-reaction is largely an academic issue since the latter two species do not infect the same hosts as does $P$. infestans.

Faint or spurious bands were observed against a few Phytophthora spp. Weak bands of the size expected for P. infestans were sporadically obtained using the AE7 primers against $P$. $h i$ bernalis (lane 16) and P. ilicis (lane 18), although this has minor consequence since neither infects potato or tomato. Bands differing in size from the $P$. infestans amplicons were seen occasionally

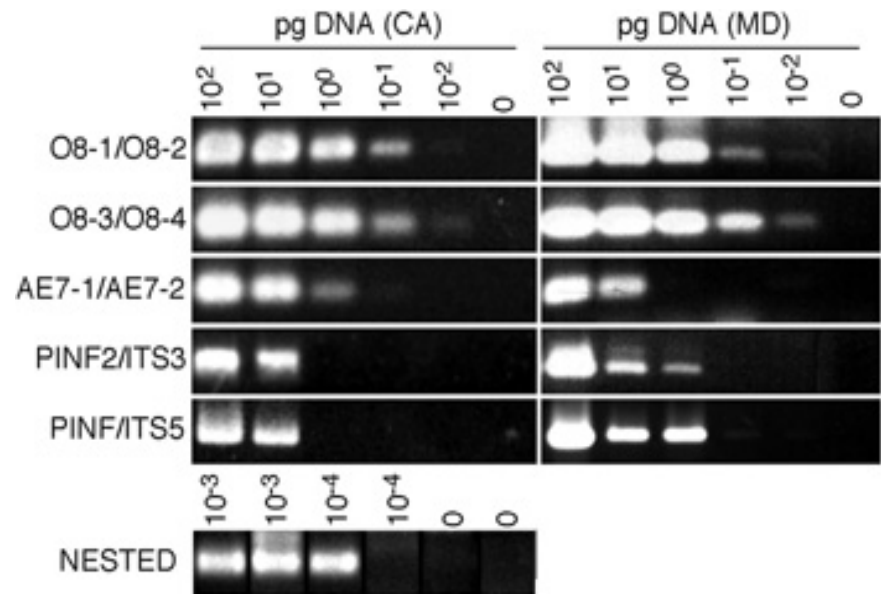

Fig. 2. Sensitivity of primers against Phytophthora infestans. The indicated primers were tested in the California and Maryland laboratories against DNA from isolates 618 and 127 , respectively. Nested polymerase chain reaction was performed with $10^{-2}$ to $10^{-4} \mathrm{pg}$ of DNA as a template; amplification was first performed (in duplicate) with primer set $08-1 / 08-4$, and then a 1:25 dilution of that reaction was amplified using the 08-3/O8-4 set. Data shown are representative of at least four replicates.

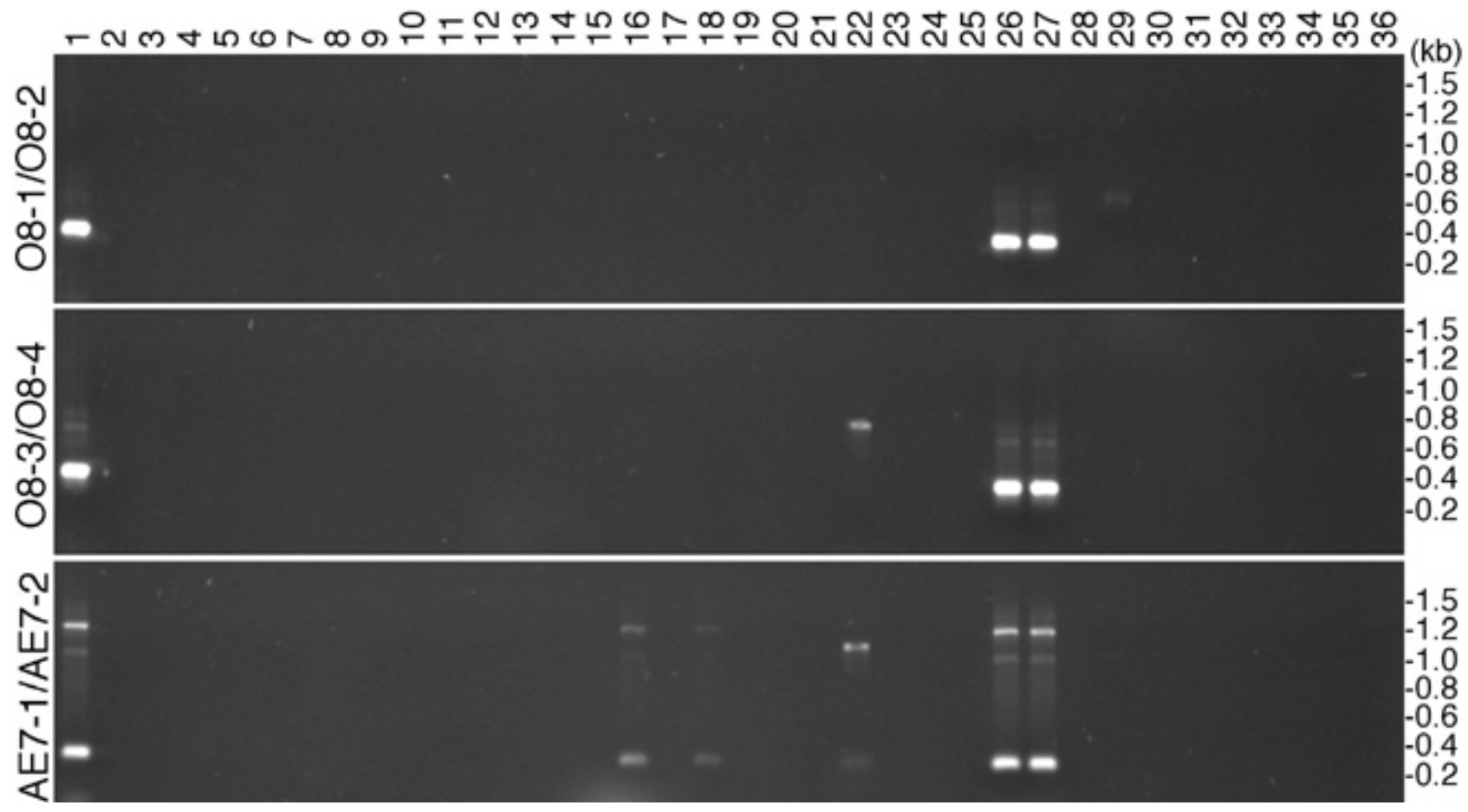

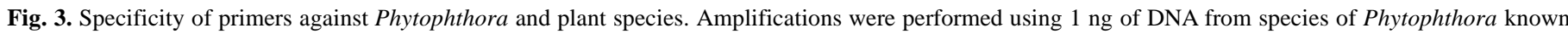

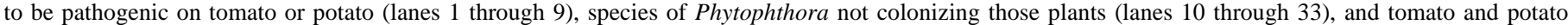

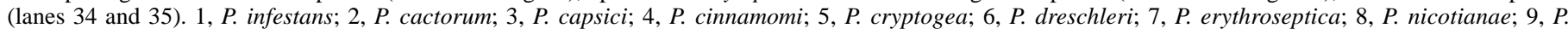

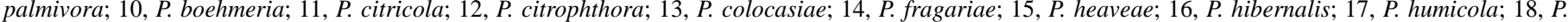

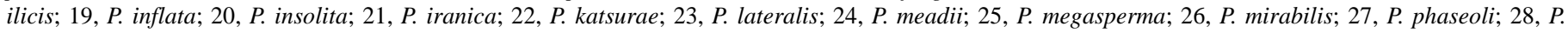

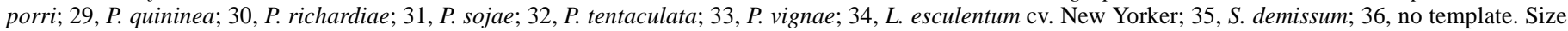
standards were determined by a 100-bp ladder. Data shown are from California laboratory. 
(i.e., not in all replicates) using 08-1/08-2 with $P$. quininea (lane 29), O8-3/O8-4 with P. katsurae (lane 22) and P. capsici (lane 3), and AE7-1/AE7-2 with P. katsurae.

The robustness of the specificity of the AE7 and O8 primer sets was tested over a range of conditions. Similar results were obtained whether amplification was performed at $0.6,1.0,1.5$, or $2.0 \mathrm{mM} \mathrm{Mg}{ }^{2+}$; $\mathrm{pH} 8.2,8.5$, or $8.8 ; 40$ or $65 \mathrm{mM}$ salt; 0 or $0.1 \%$ Triton X-100; 0.2 or $1.0 \mu \mathrm{M}$ of each primer; and 0.05 or $0.1 \mathrm{mM}$ dNTPs.

Results between CA and MD varied only slightly. Discrepancies generally involved Phytophthora spp. that are classified in Group IV of the Waterhouse scheme, where P. infestans is also placed (33). This was examined in detail for the 08-3/08-4 primers, where $P$. ilicis and $P$. colocasiae yielded weak bands in MD but none in CA (Fig. 4, bottom three groups of panels). The possibility that this reflected differences in quality, purity, or source isolate of the DNA was excluded by sharing DNA between CA and MD. The sporadic amplification of weak bands from P. colocasiae and $P$. ilicis has little practical significance since neither

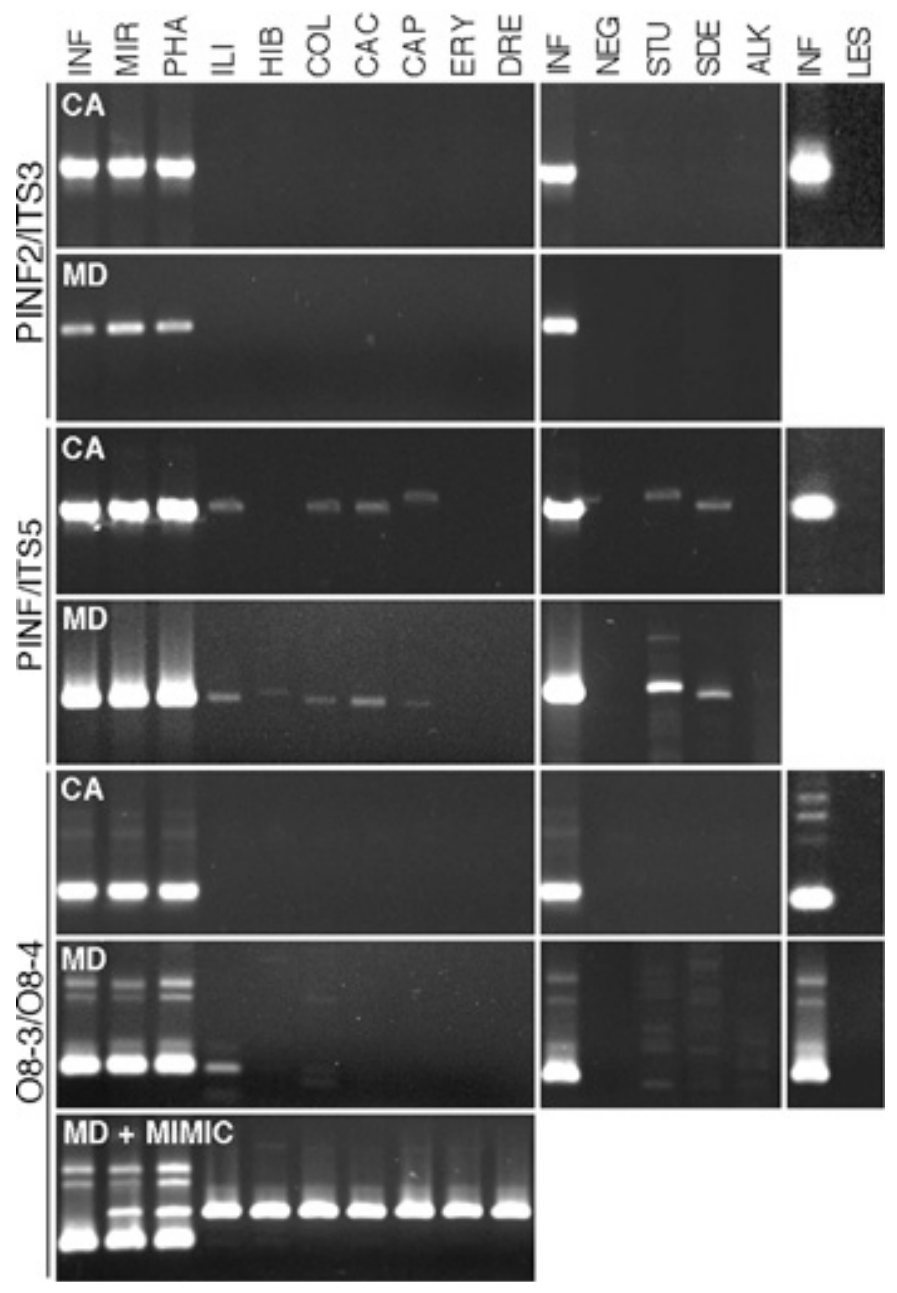

Fig. 4. Specificity of O8 and ITS primers in California (CA) and Maryland (MD) laboratories and effect of mimic. Polymerase chain reaction (PCR) was performed using PINF/ITS5, PINF2/ITS3, or O8-3/O8-4 as indicated; the source of the data (CA or MD) is labeled within each row. Left panel, PCR using $0.1 \mathrm{ng}$ of DNA from Phytophthora infestans (INF), other members of Waterhouse group IV (P. mirabilis [MIR], P. phaseoli [PHA], P. ilicis [ILI], $P$. hibernalis [HIB], P. colocasiae [COL]), and selected potato or tomato pathogens (P. cactorum [CAC], P. capsici [CAP], P. erythroseptica [ERY], and $P$. dreschleri $[\mathrm{DRE}]$ ). Middle panel, 1 ng DNA from $P$. infestans (INF), no template (NEG), $1 \mathrm{ng}$ of DNA from $S$. tuberosum cv. Katadhin (STU); 1 ng DNA from $S$. demissium (SDE); DNA extracted from $1 \mathrm{mg}$ tuber tissue using the $\mathrm{NaOH}$ method (ALK). Right panel, $1 \mathrm{ng}$ DNA from $P$. infestans (INF) and L. esculentum cv. New Yorker (LES). In the bottom row, $5 \mathrm{fg}$ of amplification mimic was included in reactions. infects potato or tomato; the fact that pathogenic species such as $P$. capsici, $P$. erythroseptica, and $P$. dreschleri were negative at both sites (Fig. 4) is more noteworthy.

A second example of results varying between the laboratories was that in $\mathrm{MD}$, but not $\mathrm{CA}$, the O8-3/O8-4 primers often generated weak bands from potato ( $S$. tuberosum and $S$. demissum). The potato bands were easily distinguished from the P. infestans amplicons by size, however. The minimum threshold for amplification, in terms of nanograms of template DNA, was $10^{6}$ to $10^{7}$ higher for potato than $P$. infestans. Based on exchanges of DNA between $\mathrm{CA}$ and $\mathrm{MD}$, the ability to amplify bands from potato was shown to be location-specific. Such bands were only obtained in CA when unrealistically large amounts of template (100 ng) were employed. Raising annealing temperatures to $54^{\circ} \mathrm{C}$ improved specificity, but reduced sensitivity for $P$. infestans by twofold.

Since the 08 and AE7 primers behaved slightly differently in $\mathrm{CA}$ and MD, the specificities of ITS primers were also examined (Fig. 4, top four rows). The PINF2/ITS3 combination showed good specificity in both sites. The PINF/ITS5 set behaved similarly in CA and MD but $1 \mathrm{ng}$ of DNA from potato yielded bands that were close in size to the $P$. infestans amplicon. That this resulted from using contaminated potato DNA was considered but excluded by several criteria, including obtaining DNA from other laboratories or tissue culture plantlets which should be devoid of $P$. infestans. Nevertheless, the PINF/ITS5 primers should still be useful for most diagnostic assays since no bands were detected using DNA from small amounts of tuber tissue, which is relatively low in potato DNA.

Development of amplification mimic. A mimic, or competitor, for the 08-3/O8-4 amplicon was developed as a control for diagnostic assays and a standard for quantitative PCR. Candidates were generated by low-stringency PCR against E. coli DNA; a 390-bp band with O8-3 and O8-4 at either end was selected and cloned into a plasmid. The minimum mass of template plasmid that reliably yielded this band was $0.2 \mathrm{fg}$, or 54 copies. Up to $5 \mathrm{fg}$ did not obviously inhibit amplification of the native 260-bp band when mixed with 1 to $1,000 \mathrm{fg}$ of $P$. infestans DNA (Fig. 5) or DNA from infected tubers (Fig. 6), supporting its utility as a control against false negatives in diagnostic PCR. Note that the ab-

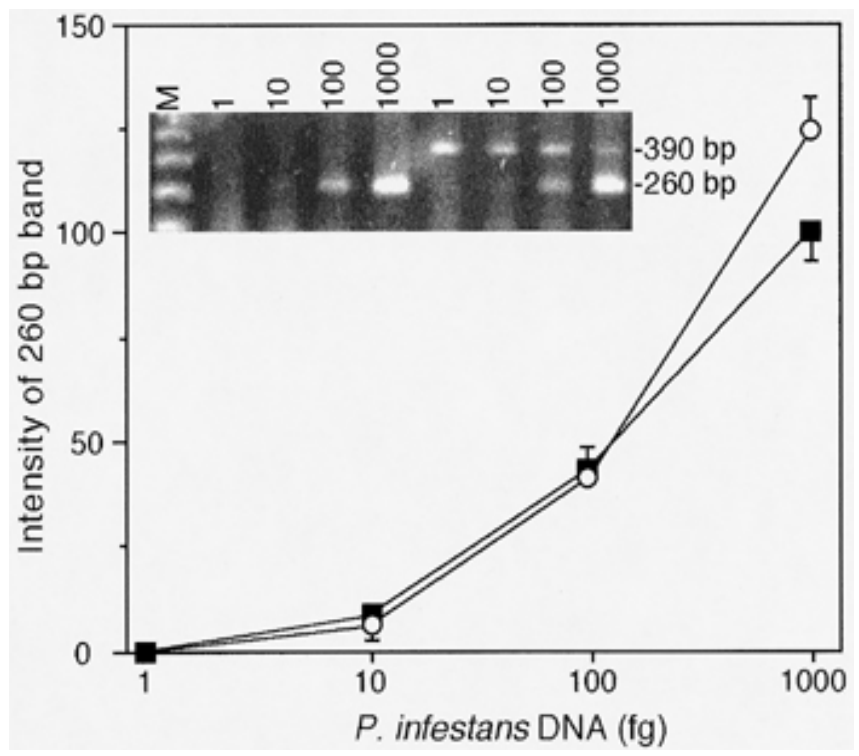

Fig. 5. Effect of mimic on sensitivity. A dilution series of Phytophthora infestans DNA (isolate 550) was subjected to PCR using primer set O8-3/O84 in the presence ( $\square)$ or absence $(O)$ of $5 \mathrm{fg}$ of mimic plasmid. Band intensities were measured after electrophoresis of the reaction products in the presence of ethidium bromide. The 390 and 260-bp bands shown in the photograph correspond to mimic and native $P$. infestans amplicons, respectively. Lanes labeled 1 to 1,000 indicate the amount of $P$. infestans DNA per reaction (in fg), and lane M contains a 123-bp ladder. 
sence of the mimic amplicon in most infected tubers is expected due to competition; the mimic serves as a positive control in otherwise negative samples. Attempts to generate a suitable O81/O8-2 mimic were unsuccessful.

The 08-3/O8-4 mimic exerted either beneficial or neutral effects on specificity. Inclusion of $5 \mathrm{fg}$ of the mimic with DNA from the species listed in Table 2 yielded no bands not observed earlier, and weak bands previously noted in MD for P. ilicis and P. colocasiae became nearly imperceptible (Fig. 4, bottom panel). Spurious bands previously seen in CA (as from $P$. katsurae) did not amplify in the presence of the mimic, but amplification from $P$. mirabilis and P. phaseoli was unaffected.

The mimic also was validated as an appropriate competitor for quantitative PCR. This was shown by coamplifying $40 \mathrm{pg}$ of $P$. infestans DNA with amounts of mimic plasmid that contained the number of copies of $\mathrm{O} 8$ in 4.8 to $1,400 \mathrm{pg}$ of $P$. infestans DNA, as calculated based on the estimated copy number of the target sequence (15; Fig 7A). The $\log _{10}$ of the PCR product ratio (390-bp/ 260-bp bands) displayed a linear relationship versus $\log _{10}$ [mimic] over $>2$ orders of magnitude (Fig. 7B). This confirms the mimic's suitability as a competitor for quantitative PCR (10).

Quantification of $\boldsymbol{P}$. infestans in tomato. The growth of $P$. infestans during compatible and incompatible interactions on tomato leaflets was studied by quantitative PCR using O8-3 and O8-4, and the results were compared to assessments of lesion size (Fig. 8). This involved cultivars bearing resistant and susceptible alleles of resistance gene Phl (New Yorker and Pieraline, respectively) challenged with isolate 618 , which expresses the matching Lel avirulence gene (27). Differences between the two types of assays were apparent, which was anticipated since lesions largely result from plant response and not pathogen growth per se. For example, lesion area increased late on the resistant plant whereas DNA levels fell, which might reflect the degradation of DNA within dying hyphae. DNA levels in the compatible interaction also outpaced lesion area after day two, perhaps because lesion measurements understate the three-dimensional growth of the pathogen.

\section{DISCUSSION}

Several methods for diagnosing late blight have been reported, including PCR. Despite its advantages, PCR has limitations. For example, primers and reaction conditions conferring suitable sensitivity are required; high sensitivity is imperative for $P$. infestans due to the devastating nature of late blight and the need to diag-

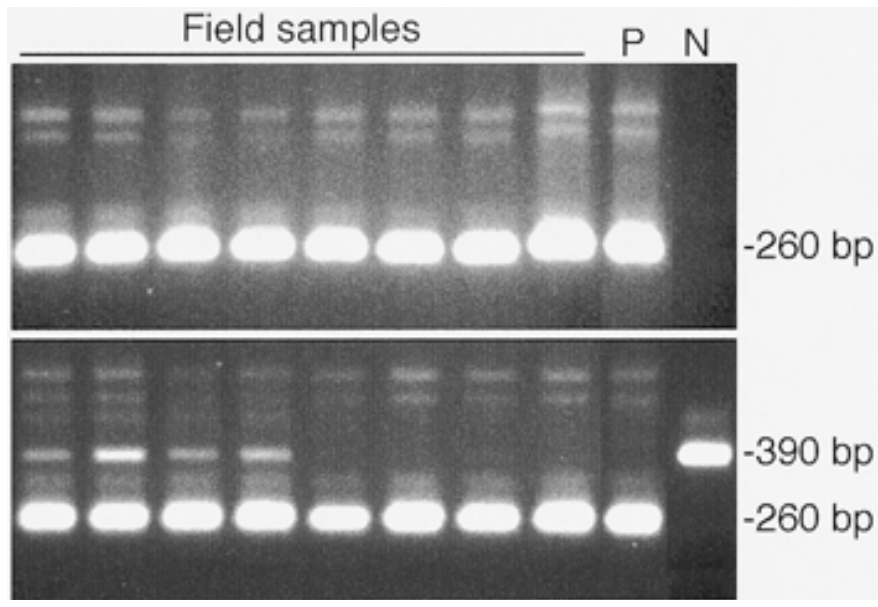

Fig. 6. Detection of Phytophthora infestans in tubers. Tubers (cv. Katahdin) showing symptoms of late blight were obtained from a field in Maine. DNA was extracted using the $\mathrm{NaOH}$ method and subjected to polymerase chain reaction using primer set O8-3/O8-4 without (top panel) or with (bottom) $5 \mathrm{fg}$ of mimic plasmid. Lane P, positive control. Lane N, negative control. nose young lesions. Specificity is required to avoid erroneous positives, and false negatives due to procedural errors or amplification inhibitors must be managed. Previous PCR methods for $P$. infestans did not address quantification, except for a recent study using expensive fluorescence PCR equipment (2), or false negatives. This study addresses the above issues by introducing new primers with enhanced sensitivity and good specificity, plus an amplification mimic to identify false negatives and enable quantification. Furthermore, the robustness of the assays was tested by replicating experiments in two locations using independent reagents.

The O8-based primers exhibited higher sensitivity than those previously reported, based on side-by-side multilaboratory comparisons with ITS primer sets and published values for others. This is likely due to the higher abundance of the 08 target, which is about 14,000 copies per nucleus. This compares to about 820 and 30 copies, respectively, of the ITS region (15) and the target used by Niepold and Schöber-Butin (22). All applications may not require the high sensitivity of the $\mathrm{O} 8$ primer sets, but such levels of sensitivity should engender increased accuracy when testing for $P$. infestans in samples that contain very young lesions, those pooled from large volumes of plant tissue, material containing amplification inhibitors, or specimens containing partially degraded DNA. The internal positive control represents another advance in PCR technology for $P$. infestans. The importance of internal standards in excluding false negatives is accepted in medical applications of PCR $(5,28)$. Internal controls are only occasionally adopted for plant pathogens (14), which is inappro-
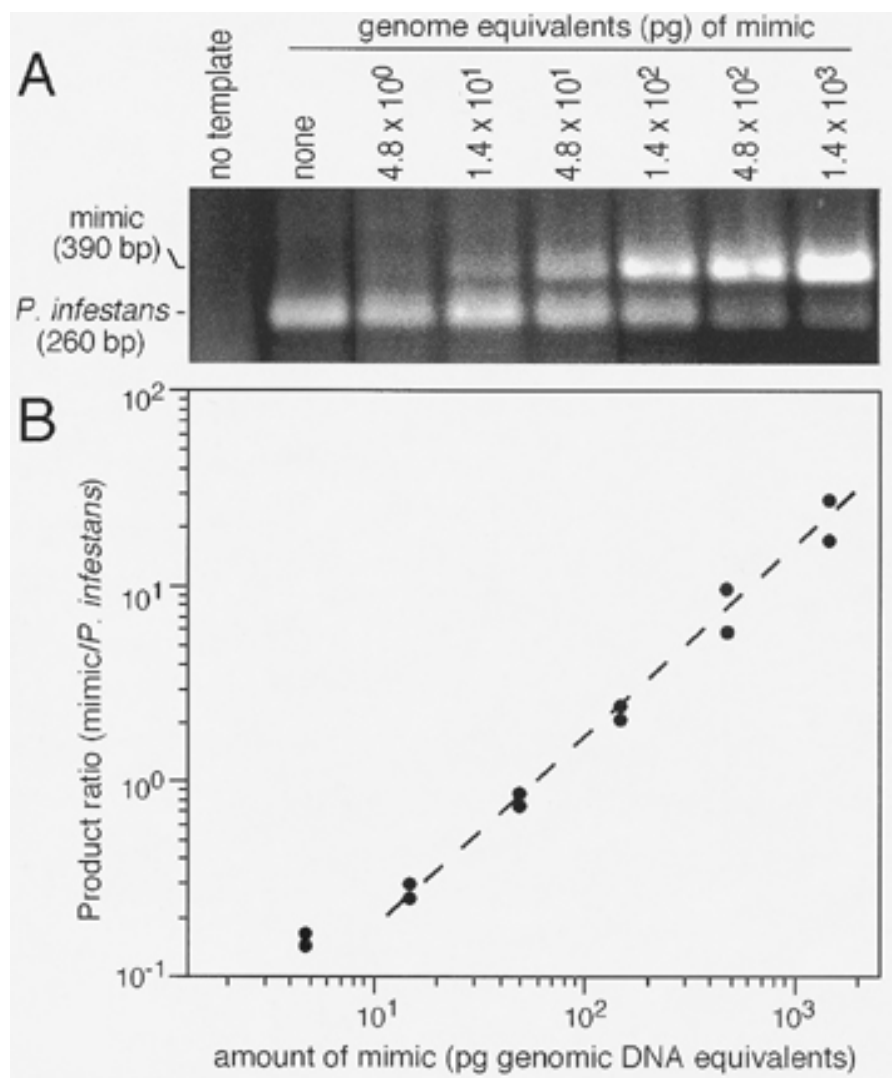

Fig. 7. Interaction between mimic and native amplicons during polymerase chain reaction. Genomic DNA of Phytophthora infestans (40 pg) and increasing amounts of the mimic plasmid (corresponding to the number of copies of $\mathrm{O} 8$ in 0 to $1.4 \times 10^{3} \mathrm{pg}$ of $P$. infestans DNA) were subjected to PCR using primer set $08-3 / 08-4$, and reaction products were quantified after electrophoresis in the presence of ethidium bromide. Two replicates were measured. A, Gel of reaction products from one of the replicates. The leftmost reaction contained neither mimic nor $P$. infestans DNA. Indicated are the mimic and genomic amplicons (390 and $260 \mathrm{bp}$, respectively). B, Ratio of band intensities (390 bp/260 bp) versus amount of mimic. A 1:1 slope is represented by the dashed line. 
priate considering that crude template preparations, which may contain inhibitors, are generally used; a mere $10 \%$ reduction in amplification per cycle may reduce sensitivity 40-fold after 35 cycles $\left(0.9^{35}\right)$. Using minimal amounts of control template also contributes to quality control by ensuring that PCR is at peak efficiency. An internal coamplified control has advantages over parallel controls because only the former identifies random failures caused by mispipetting, inhibitors, bad wells in gels, and other factors.

The control amplicon also enabled the quantitative measurement of $P$. infestans by competitive PCR using a dilution series of mimic. Semi-quantitative data may also be obtained from a single reaction since the intensity of the mimic amplicon falls as the $P$.

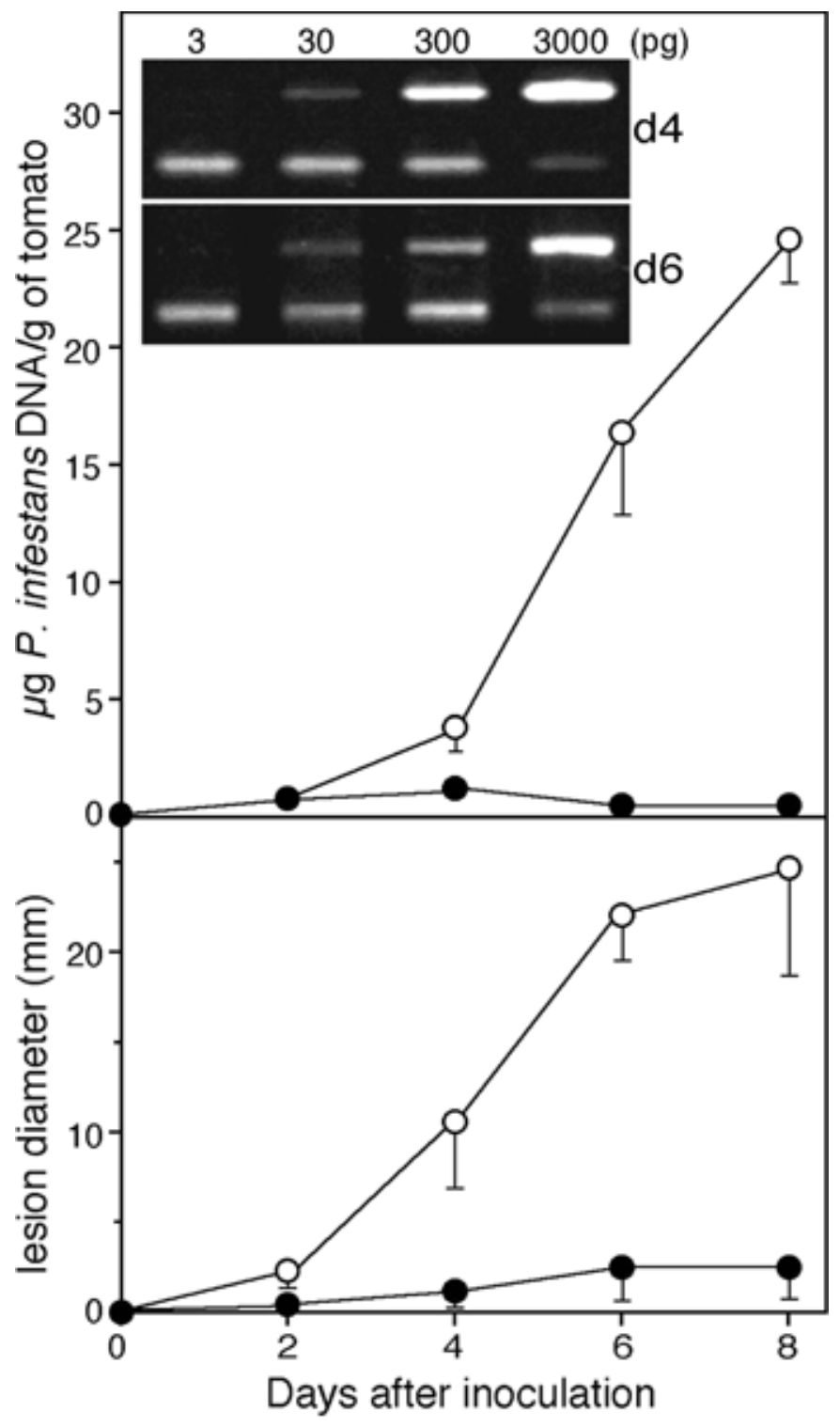

Fig. 8. Measurement of Phytophthora infestans in tomato leaflets by competitive polymerase chain reaction. Leaflets of resistant cv. New Yorker (0) and susceptible cv. Pieraline $(O)$ were inoculated with isolate 618 and incubated at $15^{\circ} \mathrm{C}$. DNA was extracted from two pools of eight leaflets per tomato genotype at each time-point. $P$. infestans DNA per gram of tomato tissue (top panel) was determined by measuring the intensity of mimic and $P$. infestans amplicons in each reaction, and then calculating the mimic concentration at which those bands would have had the same intensity; the resulting equivalence point (10) would indicate the concentration of $P$. infestans target DNA in the sample. Error bars represent variation between duplicate pools. The photograph shows representative assays at days 4 and 6 on cv. Pieraline, with mimic concentrations corresponding to $3,30,300$, and $3,000 \mathrm{pg}$ of $P$. infestans DNA. Average lesion diameters ( \pm standard deviation) are shown in the bottom panel. Error bars within symbols are not shown. infestans target increases. Quantification should also be possible using the $\mathrm{O} 8$ primers in fluorescence PCR, although such technology may be too expensive for broad adoption.

An issue that was stressed in this paper is that PCR results between different laboratories may vary even when similar protocols are employed. Anecdotal reports of such phenomena are common yet rarely reach the scientific literature (23); the point is worth emphasizing considering the diverse experience of workers adopting PCR. For the O8 primers, deviations in sensitivity and specificity were minor and inconsequential. The major difference noted was that only in MD did weak bands sometimes amplify from potato, although these were readily distinguished from the $P$. infestans band and, arguably, might be beneficial as a positive control. In contrast, for the AE7 primers, major disparities in sensitivity were noted between CA and MD. Specificity also varied for ITS3/PINF in CA, MD, and in Trout et al. (32).

Explanations for differences between laboratories can be proposed. Reagents such as water, primer, nucleotides, and DNA polymerase can vary in quality. It might be practical to standardize such variables, but not others such as the thermal cycler; heating and cooling rates of different models vary substantially, for example, influencing the specificity of PCR $(6,34)$. A point to be stressed is that uniformity in reagents and equipment is difficult to achieve in the real world. We consequently propose that authors of manuscripts describing diagnostic PCR assays should have a colleague in another laboratory test their assay. This is rarely the case outside of medical or forensic applications (35).

In response to conversations with $J$. Ristaino made after acceptance of the manuscript, we tried to address why the PINF/ITS5 primers exhibited inferior specificity in the current study compared to that noted by Trout et al. (32). We therefore performed a side-by-side comparison using DNA from potato, $P$. capsici, and $P$. infestans with the PINF/ITS5 primers as described in this paper (using thin-wall tubes, 25- $\mu$ l reactions with no mineral oil overlays, and a fast-cycling thermal cycler with 30,30 , and $60 \mathrm{~s}$ denaturation, annealing, and extension times, respectively) and by Trout et al. (thick-wall tubes, 50- $\mu$ l reactions with mineral oil, and longer cycling times in a different thermal cycler). Using the latter conditions, nonspecific bands were generally not obtained against potato or $P$. capsici. However, this came at the cost of a 10-fold reduction in the sensitivity of detection of $P$. infestans DNA. This supports the point made previously in Discussion that primer sets can exhibit divergent behavior in different laboratories due to variables that may be unanticipated or impractical to control.

\section{ACKNOWLEDGMENTS}

This study received partial support from NSF award MCB-9722947. We thank M. Carras for technical assistance and the donors of strains and DNA listed in the text.

\section{LITERATURE CITED}

1. Anonymous. 1998. California Tomato Grower 40:4-6.

2. Böhm, J., Hahn, A., Schubert, R., Bahnweg, G., Adler, N., Nechwatal, J., and Oehlmann, O. 1999. Real-time quantitative PCR: DNA determination in isolated spores of the mycorrhizal fungus Glomus mosseae and monitoring of Phytophthora infestans and Phytophthora citricola in their respective host plants. J. Phytopathol. 147:409-416.

3. Bonants, P., Hagenaar-De Weerdt, M., Van Gent-Pelzer, M., Lacourt, I. Cooke, D., and Duncan, J. 1997. Detection and identification of Phytophthora fragariae Hickman by the polymerase chain reaction. Eur. J. Plant Pathol. 103:345-355.

4. Coelho, A. C., Cravador, A., Bollen, A., Ferraz, J. F. P., Moreira, A. C., Fauconnier, A., and Godfroid, E. 1997. Highly specific and sensitive non-radioactive molecular identification of Phytophthora cinnamomi. Mycol. Res. 101:1499-1507.

5. Cone, R. W., Hobson, A. C., and Huang, M. W. 1992. Coamplified positive control detects inhibition of polymerase chain reactions. J. Clin. Microbiol. 30:3185-3189. 
6. De Zoysa, A. S., and Efstratiou, A. 1999. PCR typing of Corynebacterium diphtheriae by random amplification of polymorphic DNA. J. Med. Microbiol. 48:335-340.

7. Dorrance, A. E., and Inglis, D. A. 1997. Assessment of greenhouse and laboratory screening methods for evaluating potato foliage for resistance to late blight. Plant Dis. 81:1206-1213.

8. Ersek, T., Schoelz, J. E., and English, J. T. 1994. PCR amplification of species-specific DNA sequences can distinguish among Phytophthora species. Appl. Environ. Microbiol. 60:2616-2621.

9. Farr, D. F., Bills, G. F., Chamuris, G. P., and Rossman, A. Y. 1989. Fungi on Plants and Plant Products in the United States. The American Phytopathology Society, St. Paul, MN.

10. Freeman, W. M., Walker, S. J., and Vrana, K. E. 1999. Quantitative RTPCR: Pitfalls and potential. Biotechniques 26:112-125.

11. Fry, W. E., and Goodwin, S. B. 1997. Reemergence of potato and tomato late blight in the United States. Plant Dis. 81:1349-1357.

12. Harrison, J. G., Barker, H., Lowe, R., and Rees, E. A. 1990. Estimation of amounts of Phytophthora infestans mycelium in leaf tissue by ELISA enzyme-linked immunosorbent assay. Plant Pathol. 39:274-277.

13. Henson, J. M., and French, R. 1993. The polymerase chain reaction and plant disease diagnosis. Annu. Rev. Phytopathol. 31:81-109.

14. Honeycutt, R., Sobral, B. W. S., and McClelland, M. 1997. Polymerase chain reaction (PCR) detection and quantification using a short PCR product and a synthetic internal positive control. Anal. Biochem. 248: 303-306.

15. Judelson, H. S., and Randall, T. A. 1998. Families of repeated DNA in the oomycete Phytophthora infestans and their distribution within the genus. Genome 41:605-615.

16. Judelson, H. S., and Whittaker, S. L. 1995. Inactivation of transgenes in Phytophthora infestans is not associated with their deletion, methylation, or mutation. Curr. Genet. 28:571-579.

17. Kamoun, S., van West, P., and Govers, F. 1998. Quantification of late blight resistance of potato using transgenic Phytophthora infestans expressing $\beta$-glucuronidase. Eur. J. Plant Pathol. 104:521-525.

18. Lacourt, I., and Duncan, J. M. 1997. Specific detection of Phytophthora nicotianae using the polymerase chain reaction and primers based on the DNA sequence of its elicitin gene ParA1. Eur. J. Plant Pathol. 103:73-83.

19. Liew, E. C. Y., MacLean, D. J., and Irwin, J. A. G. 1998. Specific PCR based detection of Phytophthora medicaginis using the intergenic spacer region of the ribosomal DNA. Mycol. Res. 102:73-80.

20. Moeller, E. M., De Cock, A. W. A. M., and Prell, H. H. 1993. Mitochondrial and nuclear DNA restriction enzyme analysis of the closely related Phytophthora species P. infestans, P. mirabilis, and P. phaseoli. J. Phytopathol. 139:309-321.

21. Murray, M. G., and Thompson, W. F. 1980. Rapid isolation of highmolecular weight plant DNA. Nucleic Acids Res. 8:4321-4325.

22. Niepold, F., and Schöber-Butin, B. 1995. Application of the PCR tech- nique to detect Phytophthora infestans in potato tubers and leaves. Microbiol. Res. 150:379-385.

23. Quint, W. G. V., Heijtink, R. A., Schirm, J., Gerlich, W. H., and Niesters, H. G. M. 1995. Reliability of methods for Hepatitis B virus DNA detection. J. Clin. Microbiol. 33:225-228.

24. Ristaino, J. B., Madritch, M., Trout, C. L., and Parra, G. 1998. PCR amplification of ribosomal DNA for species identification in the plant pathogen genus Phytophthora. Appl. Environ. Microbiol. 64:948-954.

25. Schubert, R., Bahnweg, G., Nechwatal, J., Jung, T., Cooke, D. E. L., Duncan, J. M., Mueller-Starck, G., Langebartels, C., Sandermann, H., and Osswald, W. 1999. Detection and quantification of Phytophthora species which are associated with root-rot diseases in European deciduous forests by species-specific polymerase chain reaction. Eur. J. For. Pathol. 29:169-188.

26. Secor, G. A., and Gudmestad, N. C. 1999. Managing fungal diseases of potato. Can. J. Plant Pathol. 21:213-221.

27. Spielman, L. J., Mcmaster, B. J., and Fry, W. E. 1989. Dominance and recessiveness at loci for virulence against potato and tomato in Phytophthora infestans. Theor. Appl. Genet. 77:832-838.

28. Thoreson, A.-C. E., Borre, M., Andersen, L. P., Jorgensen, F., Kiilerich, S., Scheibel, J., Rath, J., and Krogfelt, K. A. 1999. Helicobacter pylori detection in human biopsies: A competitive PCR assay with internal control reveals false results. FEMS Microbiol. Immunol. 24:201-208.

29. Tooley, P. W., Bunyard, B. A., Carras, M. M., and Hatziloukas, E. 1997. Development of PCR primers from internal transcribed spacer region 2 for detection of Phytophthora species infecting potatoes. Appl. Environ. Microbiol. 63:1467-1475.

30. Tooley, P. W., Carras, M. M., and Falkenstein, K. F. 1996. Relationships among Group IV Phytophthora species inferred by restriction analysis of the ITS2 region. J. Phytopathol. 144:363-369.

31. Tooley, P. W., and Therrien, C. D. 1987. Cytophotometric determination of the nuclear DNA content of 23 Mexican and 18 non-Mexican isolates of Phytophthora infestans. Exp. Mycol. 11:19-26.

32. Trout, C. L., Ristaino, J. B., Madritch, M., and Wangsomboondee, T, 1997. Rapid detection of Phytophthora infestans in late blight-infected potato and tomato using PCR. Plant Dis. 81:1042-1048.

33. Waterhouse, G. M., Newhook, F. J., and Stamps, D. J. 1983. Present criteria for classification of Phytophthora. Pages 130-147 in: Phytophthora: Its Biology, Taxonomy, Ecology, and Physiology. D. C. Erwin, S. Bartinicki-Garcia, and P. H. Tsao, eds. The American Phytopathological Society, St. Paul, MN.

34. Wittwer, C. T., and Garling, D. J. 1991. Rapid cycle DNA amplification: time and temperature optimization. Biotechniques 10:76-83.

35. Word, C. J., Sawosik, T, M., and Bing, D. H. 1997. Summary of validation studies from twenty-six forensic laboratories in the United States and Canada on the use of the AmpliType PM PCR amplification and typing kit. J. Forensic Sci. 42:39-48. 